\title{
Management of Microsprinkler Systems for Florida Citrus ${ }^{1}$
}

\section{R. Parsons and K. T. Morgan ${ }^{2}$}

Irrigation is an essential part of the Florida citrus production system. In one study, irrigation increased yield by 39 to $64 \%$ over the non-irrigated controls. Microsprinkler irrigation systems have become the standard for Florida citrus. Microsprinkler and drip systems have been collectively referred to as trickle, low volume irrigation, or microirrigation systems. Compared to overhead sprinklers, low volume systems can save water if they are properly managed. Because these systems usually operate at lower pressures than conventional overhead systems, there can also be appreciable savings from reduced energy costs. In addition, microsprinkler irrigation can provide partial frost protection for both young and mature trees.

\section{Irrigation System Design}

Design of the irrigation system is of prime importance, and the system should be designed to meet mature tree water needs. For maximum efficiency, the system should provide sufficient water uniformly throughout the grove. Depending on tree size, time of year, and tree spacing, mature trees can use from 8 to 80 gallons of water per day. Mature trees in lower density plantings are usually larger and use more water per tree. Trees in higher density plantings are usually smaller and use less water per tree. With 140 trees/acre ( $25 \times 12.5$ foot spacing), tree water use from winter to summer can range from 14 to 39 gallons/day. With 218 trees/acre $(20 \times 10$ foot spacing), water use per tree can range from 9 to 25 gallons/day. Most drippers emit around 0.5 to 2.0 gallons per hour, and microsprinklers commonly deliver between 7 and 25 gallons per hour.

Good surface area coverage is an important aspect in maximizing yields in Florida's sandy soils. One reason that coverage is important is that roots of mature trees extend horizontally throughout much of the soil area because of Florida's abundant natural rainfall. Several studies have shown that yield increases directly with the increase in ground coverage by the irrigation treatments.

Drip emitter spacing and flow rate should be designed for the specific soil texture and tree spacing. Drip systems provide coverage to only a small percentage of the root system since water from

1. This document is HS-958, one of a series of the Horticultural Sciences Department, Florida Cooperative Extension Service, Institute of Food and Agricultural Sciences, University of Florida. Date printed: October 2004. Please visit the EDIS Website at http://edis.ifas.ufl.edu.

2. L.R. Parsons, professor, Horticultural Sciences Department, Citrus REC, Lake Alfred, FL; and K.T. Morgan, assistant professor, Soil and Water Science Department, Southwest Florida REC, Immokalee, FL; Cooperative Extension Service, Institute of Food and Agricultural Sciences, University of Florida, Gainesville, 32611.

The Institute of Food and Agricultural Sciences (IFAS) is an Equal Employment Opportunity - Affirmative Action Employer authorized to provide research, educational information and other services only to individuals and institutions that function without regard to race, creed, color, religion, age, disability, sex, sexual orientation, marital status, national origin, political opinions or affiliations. For information on obtaining other extension publications, contact your county Cooperative Extension Service office. Florida Cooperative Extension Service / Institute of Food and Agricultural Sciences / University of Florida / Larry R. Arrington, Interim Dean 
drippers does not move very far horizontally in sandy soils. With young trees, one or two drippers per tree are acceptable. However, as trees mature, additional coverage is needed. Four or more drippers per tree are recommended to increase coverage. Generally speaking, more coverage will provide better yield and is worth the extra initial investment. With inadequate coverage, drip systems may not be able to meet the water needs of larger trees. Less coverage will force the grove to depend on erratic rainfall to keep the trees from becoming overly drought stressed.

One advantage of microsprinklers or spray jets is that they provide more coverage than drippers. Research has shown that on ridge sands, two spray jets per tree gave better yield than one jet per tree. One jet per tree gave better yield than either 2 or 4 drippers per tree. This stands to reason because jets cover more area than drippers.

\section{Irrigation Scheduling}

Management of microsprinkler systems is of prime importance. One of the advantages of microirrigation systems is that they can be run frequently to maintain soil moisture in an optimum range. However, it is very easy to run these systems too long and over-irrigate the wetted area. Ideally, sufficient water should be applied to wet the main root zone but not enough to cause excessive percolation and leaching of nutrients. To avoid deep percolation loss, the microsprinkler system should be operated more frequently for shorter durations. Using soil moisture sensors (e.g., tensiometers or other probes) at different depths can help reduce deep percolation loss.

Generally speaking, flatwoods soils are finer textured and have more organic material in the surface layers. This gives them a higher water-holding capacity but a lower conductivity. Hence, water moves more slowly through flatwoods soils than coarser ridge soils.

A microsprinkler system that is operated for too many hours will drive much of the water, nutrients, or agrichemicals below the main tree root system. On the ridge, mature trees on most commonly used rootstocks have over half their roots in the top 3 feet, while in the flatwoods, over $95 \%$ of the roots are in the top 12 to 18 inches. While mature trees on the ridge can have a few roots at depths exceeding 15 feet, the majority are in the top 3 feet and 30 to 50\% can be in the top one foot. For young trees, most roots are in the top 1 to 2 feet. Hence, for best management of microirrigation systems, concentrate on the top 2 to 3 feet in the ridge and the top 12 to 18 inches in the flatwoods for mature trees.

If the system is run frequently and the soil is not allowed to become excessively dry, the upper roots in the wetted zone will be adequately supplied with water. Unless the soil becomes excessively dry, there is little point in running a microsprinkler for more than 6 hours continuously. Some growers use long irrigation durations as a way to irrigate only once a week. After 6 to 9 hours, some water will have moved below the main root zone and be wasted. For frequent irrigations of shorter duration with microirrigation systems, an irrigation timer with a manual override for rainy periods would be one option to consider.

Work with overhead sprinklers (100\% coverage) has shown that it is best to irrigate at 30 to $33 \%$ depletion in the spring and $67 \%$ depletion in the fall. With mature trees, a fair percentage of roots extend into the soil area between the tree rows outside the wetted zone of the microsprinkler. Hence, not all the outer roots are wetted by the microsprinkler. Because they wet only part of the soil surface, it is suggested that depletion levels of 25 and $50 \%$ be used with microsprinklers. Keeping the irrigated zone slightly wetter will help compensate for stress on the outer roots in the dry non-irrigated zone.

A simplified rule-of-thumb guide on microirrigation frequencies and durations is shown in Table 1. Note that this table deals with both young and mature trees. For a more detailed schedule, see University of Florida Cooperative Extension Service Bulletin 208 "Trickle Irrigation Scheduling for Florida Citrus" by A. G. Smajstrla et al. Schedules for individual groves can also be obtained from the National Resource Conservation Service (NRCS). 
A range of values is presented in Table 1 because of differences in soil type, tree density, and number of emitters per acre. Growers will need to adapt their schedule based on these variables. This table assumes no rainfall between irrigation cycles. Note that with microsprinklers, the suggested duration for young trees is only 2 to 3 hours in the spring and summer. Irrigating for longer periods will only drive water below the root zone. This table was designed for spray jets with a $270^{\circ}$ or $360^{\circ}$ spray pattern. When using jets with a $90^{\circ}$ or $180^{\circ}$ spray pattern on young trees, length of irrigation should be decreased but the time interval between irrigations should remain the same. This is because $90^{\circ}$ and $180^{\circ}$ jets have a higher application rate on the wetted area and fill the soil volume quicker. Irrigation durations should be one hour or less when using jets that deflect water downward onto a small area around the young trees. A 15-gallon/hour jet spraying onto an area 3 feet in diameter is equivalent to applying 3.4 inches/hour on a wetted area of 7.07 $\mathrm{ft}^{2}$. To check depth of water penetration, use a tensiometer, moisture probe, or a soil auger to determine the depth of moist soil.

The reason for the frequent but relatively short irrigations shown in Table 1 is to reduce deep soil penetration from long duration irrigations. Note that none of the irrigation durations exceeds 6 hours. The only reason for running a system excessively is in cases of extreme drought, to raise the water table level in flatwoods sites, or for extended cold protection.

Table 2 gives information on how long irrigation can be delayed after rainfall. The soil can only hold a certain amount of water. Finer textured soils (loams and clays) can hold more water than sands. Coarse textured ridge soils hold very little water. Table 2 lists days that irrigation can be delayed after 0.25 inch increments of rainfall. Even after a heavy rainfall of more than 0.75 inch, irrigation needs to be started in 2 or 3 days after a rainfall in the spring. The reason for irrigation in the spring just a few days after a rainfall event is to promote young fruit growth and reduce fruit droppage. In the fall, irrigation can be delayed longer after a rain event because trees and fruit are not growing as rapidly then and they can tolerate more water stress. These two tables are intended to be used under average Florida conditions. The schedule and rain delay days are strongly influenced by the microsprinkler spray diameter and depth of the rooting system.

For young trees, increased growth is the main advantage of irrigating frequently for short durations. The upper soil layer where most of the roots are located is thereby kept moist and tree stress is minimized. Growth is one of the first things affected by water stress. Mild water stress slows growth and more prolonged stress stops growth entirely. The idea of irrigating every 2 to 3 days from March through October for short durations is to keep the upper soil horizon near field capacity, maximize growth, and minimize deep soil water loss. The goal of this schedule for young trees is to promote optimum growth so trees can reach production size sooner and become profitable at an earlier age.

If growers wish to reduce the amount of water applied to mature trees, they can increase the interval between irrigations by 1 or 2 days and lengthen the duration by an hour or so, particularly during the fall and winter months (October through January). This will impose a mild stress on the trees, may reduce growth slightly, and may help concentrate solids in the juice. However, irrigation should not be reduced in the spring. The interval between irrigations should not be greater than 3 to 4 days, particularly in the hotter months of May and June.

If coverage is inadequate on mature trees, the microirrigation system may not be able to meet the water requirements of the large trees. Running the system for a longer time will probably not make up for the lack of coverage, and the longer running time will drive more of the water below the main root zone. Hence, design the system to cover at least 50 to $75 \%$ of the total land area. In that way, better growth and yields can be obtained.

Table 1 gives an estimated irrigation schedule for common ridge and flatwoods soils. There are times when prolonged hot, dry spells can stress trees, and this schedule would not provide adequate water. In such cases of high evapotranspiration (ET), additional water may be necessary to reduce stress on the trees. In this case, the time interval between 
cycles should be shortened rather than lengthening the irrigation duration.

\section{Summary}

In summary, when managing a microirrigation system, keep the following points in mind:

1. Design the irrigation system to cover 50 to $75 \%$ of the total land area. More coverage commonly promotes better growth and yields.

2. Use Tables 1 and 2 as guides for irrigation frequency, duration, and delay after rainfall. Modify the schedule as needed to fit your particular soil type and irrigation system.

3. Reduce percolation by increasing frequency and decreasing length of the irrigation cycle. Since most of the roots are in the upper several feet of the soil profile, irrigation for long durations can lead to loss of water and nutrients below the root zone. 
Table 1. Citrus Microsprinkler Irrigation Schedule for Florida Citrus Under Average Conditions

\begin{tabular}{|c|c|c|c|c|c|c|c|c|}
\hline \multirow{3}{*}{ Month } & \multicolumn{3}{|c|}{$\begin{array}{c}\text { Young } \\
\text { Age }=1-3 \text { years }\end{array}$} & \multicolumn{5}{|c|}{ Mature Trees } \\
\hline & \multirow{2}{*}{$\begin{array}{l}\text { Allow. Soil } \\
\text { Water } \\
\text { Depl. } \\
(\%)\end{array}$} & \multirow{2}{*}{$\begin{array}{c}\text { Duration } \\
\text { (Hours) }\end{array}$} & \multirow{2}{*}{$\begin{array}{r}\text { Interval } \\
\text { (Days) }\end{array}$} & \multirow{2}{*}{$\begin{array}{l}\text { Allow. Soil } \\
\text { Water } \\
\text { Depl. } \\
(\%)\end{array}$} & \multicolumn{2}{|c|}{ Ridge } & \multicolumn{2}{|c|}{ Flatwoods } \\
\hline & & & & & $\begin{array}{l}\text { Duration } \\
\text { (Hours) }\end{array}$ & $\begin{array}{r}\text { Interval } \\
\text { (Days) }\end{array}$ & $\begin{array}{c}\text { Duration } \\
\text { (Hours) }\end{array}$ & $\begin{array}{r}\text { Interval } \\
\text { (Days) }\end{array}$ \\
\hline Feb. & 25 & $2-3$ & $3-4$ & 25 & $3-4$ & $3-4$ & $3-4$ & $3-4$ \\
\hline March & 25 & 3 & 3 & 25 & $3-4$ & 3 & $3-4$ & 3 \\
\hline April & 25 & $2-3$ & $2-3$ & 25 & $3-5$ & $2-3$ & 4 & $2-3$ \\
\hline July & 25 & $2-3$ & 2 & 50 & 6 & 3 & 6 & $3-4$ \\
\hline Aug. & 25 & $2-3$ & 2 & 50 & $5-6$ & $3-4$ & 6 & $3-4$ \\
\hline Sept. & 25 & $2-3$ & $2-3$ & 50 & 6 & 4 & 6 & $3-5$ \\
\hline Oct. & 25 & $2-3$ & 3 & 50 & 6 & 5 & 6 & $4-6$ \\
\hline Nov. & 50 & $3-4$ & $5-6$ & 50 & 6 & 6 & 6 & $5-8$ \\
\hline Dec. & 50 & $3-4$ & $7-8$ & 50 & $5-6$ & $7-8$ & 6 & $7-10$ \\
\hline
\end{tabular}

Table 2. Citrus Microsprinkler Irrigation Schedule - Irrigation Delay for Rainfall.

\begin{tabular}{|c|c|c|c|c|c|c|c|c|c|c|}
\hline \multirow[t]{2}{*}{ Month } & \multicolumn{10}{|c|}{ Days to Delay Irrigation Based on Rainfall Amount* } \\
\hline & \multicolumn{5}{|c|}{ Mature Trees - Ridge } & \multicolumn{5}{|c|}{ Mature Trees - Flatwoods } \\
\hline $\begin{array}{l}\text { Rain } \\
\text { (inches) }\end{array}$ & $\begin{array}{l}0.00- \\
0.24 " \\
\end{array}$ & $\begin{array}{l}0.25- \\
0.49^{\prime \prime}\end{array}$ & $\begin{array}{l}0.50- \\
0.74 " \\
\end{array}$ & $\begin{array}{l}0.75- \\
0.99^{\prime \prime}\end{array}$ & $>1.0^{\prime \prime}$ & $\begin{array}{l}0.00- \\
0.24 "\end{array}$ & $\begin{array}{l}0.25- \\
0.49 "\end{array}$ & $\begin{array}{l}0.50- \\
0.74 " \\
\end{array}$ & $\begin{array}{l}0.75- \\
0.99^{\prime \prime}\end{array}$ & $>1.0^{\prime \prime}$ \\
\hline Feb. & 1 & 3 & 4 & 4 & 4 & 1 & 3 & 4 & 4 & 4 \\
\hline March & 1 & $2-3$ & 3 & 3 & 3 & 1 & 2 & 3 & $3-4$ & $3-4$ \\
\hline April & 1 & 2 & 3 & 3 & 3 & $0-1$ & 2 & 3 & 3 & 3 \\
\hline
\end{tabular}


Table 2. Citrus Microsprinkler Irrigation Schedule - Irrigation Delay for Rainfall.

\begin{tabular}{||l|c|c|c|c|c|c|c|c|c|c|c|c||}
\hline \hline May & 0 & 1 & 2 & 2 & 2 & 0 & 1 & $2-3$ & 3 & 3 \\
\hline June & & 0 & 1 & 2 & 2 & 2 & 0 & 1 & 3 & 3 & 3 \\
\hline July & 0 & 1 & 2 & 3 & 3 & 0 & $1-2$ & 3 & $3-4$ & 4 \\
\hline Aug. & 0 & 1 & 2 & 3 & 4 & 0 & $1-2$ & 3 & 4 & 4 \\
\hline Sept. & 0 & 1 & $2-3$ & 4 & 4 & $0-1$ & 2 & 3 & 4 & $4-5$ \\
\hline Oct. & $0-1$ & 2 & $3-4$ & 5 & 5 & 1 & 2 & $3-4$ & $4-5$ & $5-6$ \\
\hline Nov. & 1 & 3 & 5 & 6 & 6 & 1 & 3 & $4-5$ & $5-7$ & $6-8$ \\
\hline \multicolumn{1}{|l|}{ Dec. } \\
\hline
\end{tabular}

